\title{
PENGEMBANGAN KETERAMPILAN ACADEMIC ENGLISH WRITING MAHASISWA SEMESTER IV JURUSAN PARIWISATA POLITEKNIK NEGERI MANADO MELALUI METODE PENERJEMAHAN
}

\author{
Agustinus Lumettu, ${ }^{1}$ and Treesje Lusje Runtuwene ${ }^{2}$ \\ Politeknik Negeri Manado
}

Agus.lumettu@gmail.com

\begin{abstract}
English competence is determined by its grammar mastery, more specifically Academic English Competence. In daily conversation, mastery of grammar is not the key point but in Academic English, the mastery of grammatical sentences is an important aspect. The general objective of this research is to prepare the higher semester students to master Academic English in order that they pass the test for further studies both in domestic and foreign universities as well as pass the test for employment recruitment both in public and private sectors that require good Academic English mastery. The specific objective of this research is to enable the target students to fulfill the requirements for undertaking internship in foreign countries and write internship report in English as well as write the Final Project I Skripsi in English. The method used in developing the students' Academic Writing Skill is Translation Method since this method provides ample grammatical exercises starting from sentence level translation, paragraph level translation and essay level translation as well as vocabulary practice. Further, the students are given examples of ideas in writing sentences, paragraphs and essays. Finally, the students are trained to write tourism topics directly in English without depending on translation. The method of this research is Qualitative method. The results of research show that translation Method is very effective in developing the students' Academic Writing Skills. The final test average score obtained by the Experimental group is $23 \%$ higher than that of the Control group.
\end{abstract}

Keywords: development, academic writing skill, translation method

\begin{abstract}
Abstrak: Kemampuan bahasa Inggris ditentukan oleh penguasaan tata bahasanya, apalagi kemampuan bahasa Inggris akademik.Memang dalam percakapan sehari-hari penguasaan tata bahasa bukanlah harga mati, namun dalam bahasa Inggris akademik, penggunaan kalimat yang gramatikal merupakan tuntutan.Tujuan umum penelitian ini adalah untuk mempersiapkan mahasiswa semester atas menguasai academic English dengan baik sehingga mereka mampu studi lanjut di dalam dan luar negeri juga berhasil lulus dalam rekruitmen tenaga kerja. Target khusus dalam penelitian ini adalah agar mahasiswa yang jadi sasaran mampu memenuhi persyaratan untuk mengikuti On The job Training di luar negeri dan menulis laporannya dalam bahasa Inggris serta menulis tugas akhir / skripsi dalam bahasa Inggris.Metode yang digunakan adalah metode penerjemahan karena metode ini menyediakan banyak sekali latihan tata bahasa yang dimulai dari menerjemahkan kalimat, paragraf dan esei. Selanjutnya mahasiswa diberi contoh yang nyata tentang gagasan dalam menulis kalimat, paragraf dan wacana. Kemudian mahasiswa dilatih dengan menulis topik - topik yang relevan dengan bidang pariwisata disertai pengembangan kosa kata bahasa Inggris dan diakhiri dengan menulis secara kreatif tanpa tergantung lagi pada latihan penerjemahan. Penelitian ini menggunakan metode kwalitatif. Hasil penelitian menunjukkan bahwa Metode penerjemahan sangat efektif dalam mengembangkan ketrampilan Academic Writing Nilai rata rata ujian akhir dari Experimental Group adalah $23 \%$ lebih tinggi dari yang Control Group.
\end{abstract}

Kata kunci: pengembangan, ketrampilan academic writing, metode penerjemahan 


\section{PENDAHULUAN}

Ketrampilan bahasa Inggris akademik sangatlah penting bagi mahasiswa semester atas baik untuk keperluan studi di perguruan tinggi maupun untuk mendapatkan pekerjaan apalagi bagi mereka yang berniat untuk studi lanjut atau untuk mengikuti seleksi Calon Pegawai Negeri Sipil ataupun karyawan swasta, kemampuan bahasa Inggris akademik dengan dibuktikan dengan sertifikat TOEFL, IELTS TOEIC, GMAT atau GRE adalah salah satu syarat utama yang harus dipenuhi. Pelatihan ketrampilan bahasa Inggris akademik termasuk preparasi tes tes internasional tersebut di atas sangat terlambat apabila nanti dilakukan setelah mahasiswa tamat dari perguruan tinggi, karena untuk itu dibutuhkan waktu dan biaya yang tidak sedikit. Akibatnya mereka harus menunggu setahun atau bahkan beberapa tahun untuk bisa mendapatkan peluang studi lanjut karena belum lulus tes bahasa Inggris akademik. Selain itu sebahagian lagi harus berkali kali gagal dalam rekrutmen pegawai negeri maupun swasta karena tidak lulus tes bahasa Inggris akademik. Dari keempat ketrampilan bahasa Inggris akademik, academic writing adalah yang paling rumit karena membutuhkan ketepatan dalam gagasan, pilihan kata dan terutama tata bahasa. Karena itu untuk menjembatani proses kreatif menuju academic writing, penulis memilih untuk menggunakan metode penerjemahan terutama terjemahan dari bahasa Indonesia ke bahasa Inggris, karena metode ini menyediakan banyak sekali latihan grammar mulai menerjemahkan kalimat, paragraf dan wacana yang tentunya harus secara gramatikal. Kemampuan menggunakan kalimat yang gramatikal ini menjadi tulang punggung academic writing. Selain sangat efektif untuk aplikasi berbagai topik dalam grammar, metode penerjemahan juga efektif dalam membantu memperkaya gagasan dan kosa kata yang merupakan 2 unsur penting lainnya dalam academic writing. Sehingga penerjemahan menjadi jembatan menuju kreatifitas menulis akademik, dimulai dengan latihan menerjemahkan kalimat, paragraf, wacana dari bahasa Indonesia ke bahasa inggris dan diakhiri dengan menulis secara kreatif tanpa tergantung lagi pada latihan penerjemahan. Penggunaan metode penerjemahan adalah adalah suatu cara yang efektif untuk mengembangkan keterampilan menulis bahasa Inggris akademik mulai dari tataran kalimat, paragraf sampai pada wacana. Dalam penerjemahan terlibat banyak aspek, topik topik tata bahasa dan latihan-latihan terjemahan terutama terjemahan-terjemahan dari bahasa Indonesia ke bahasa Inggris akan memperluas penguasaan tata bahasa yang merupakan hal yang wajib dalam academic writing. Semakin banyak latihan penerjemahan, semakin kokoh penguasaan tata bahasa yang bersifat aplikatif, variatif dan repetitif yang merupakan kombinasi yang efektif untuk mengembangkan kemampuan menulis akademik mahasiswa.

\section{TINJAUAN PUSTAKA}

\section{Bahasa}

Rasjid, Mansyur dan Suratno (2009) menyatakan bahwa bahasa merupakan struktur dan makna yang bebas dari penggunanya sebagai tanda yang mengnyimpulkan suatu tujuan sedangkan adalah alat untuk berkomunikasi satu sama lain dan berupa symbol bunyi yang berasal dari alat ucap yang dimiliki manusia, sedangkan Collins English Dictionary dalam https//www.collinsdictionary.com) mendifinisikan bahasa sebagai a system of communication which consist of a set of sounds and written symbols which are used by the peopleof a particicular countryor region for taking or writing. Dari dua definisi di atas dapatlah disimpulkan bahwa bahasa adalah gabungan simbol bunyi yang mana suka (arbitrer) yang menciptakan pengertian yang dipahami oleh suatu masyarakat sehingga menjadi alat komunikasi antara satu dengan yang lainnya.

\section{English Academic Writing Skill}

Writing merupakan suatu media komunikasi manusia yang mempresentasikan bahasa dan emosi dengan tanda dan simbol. Pada kebanyakan bahasa, writing (menulis) adalah pelengkap 
bagi bahasa lisan (spoken language). Writing bukanlah sebuah bahasa tetapi sebuah alat yang membuat bahasa bisa dibaca. Academic writing (sana.aatto.fi) menyatakan writing comprises many different types of text, ranging from a research article, written for publication in an academic journal to a MSC dissertation to an essay written for a university course, moreover, text types are constantly evolving as our universities and society change. Sejalan dengan ini Labare (2009) menyebutkan bahwa Academic Writing merujuk pada suatu gaya ekspresi yang digunakan untuk mendefinisikan batas batas intelektual dari suatu bidang dengan lingkup keahlian tertentu. Academic Writing meliputi suatu nada yang formal, penggunaan sudut pandang orang ketiga tunggal ketimbang sudut pandang orang pertama, fokus masalah penelitian yang jelas dan pilihan kata yang tepat. Hampir senada dengan itu, MY Cumbria menekankan bahwa Academic Writing adalah suatu gaya khusus esei formal dan jenis jenis evaluasi yang lain dalam mata kuliah anda. Gaya ini menuntut penggunaan bahasa formal, struktur yang logis dan didukung oleh bukti. Dari pernyataan di atas jelaslah bahwa academic writing mencakup penulisan tugas akhir, skripsi, thesis, desertasi, artikel ilmiah untuk publikasi, esei untuk publikasi atau sebagai jawaban tes dalam sebuah tes bahasa Inggris akademik seperti TOEFL, IELTS, GRE dll serta laporan praktek/ laporan bisnis. Suparno (2009) bahwa menulis merupakan komunikasi tidak langsung yang berupa pemindahanpikiran atau perasaan dengan memanfaatkan grafologi, struktur bahasa dan kosakata dengan menggunakan symbol sehingga dapat dibaca seperti apa yang diwakili oleh symbol symbol tersebut.

\section{Pengembangan.}

Pengembangan adalah suatu usaha untuk meningkatkan kemampuan teknis, teoritis, konseptual dan moral sesuai dengan kebutuhan melalui pendidikan dan latihan. Dengan demikian, pengembangan pembelajaran adalah usaha meningkatkan kualitas proses

pembelajaran baik secara materi maupun metode dan subtitusinya (respiratory.radenintan.ac.id $>$ BAB II). Senada dengan ini, Cambridge English Dictionary mendefinisikan pengembangan sebagai suatu proses dimana seseorang atau sesuatu bertumbuh dan berubah dan menjadi lebih maju. (https://dictionary.cambridge.org>development). Seels dan Richey dalam Alim Sumarno (2012) mendefinisikan pengembangan sebagai suatu proses menterjemahkan atau menggambarkan spesifikasi rancangan ke dalam bentuk fitur fisik. Pengembangan secara khusus berarti proses menghasilkan bahan-bahan pembelajaran. Sedangkan menurut Tessmer dan Richey dalam Alim Sumarno (2012) pengembangan memusatkan perhatiannya tidak hanya pada analisis kebutuhan tapi juga isu-isu luas tentang analisis awalakhir seperti analisis kontekstual.

\section{Metode Penerjemahan (Translation Method)}

Oxford Dictionary mendefinisikan penerjemahan (translation) sebagai interpretasi makna dari bahasa sumber untuk menghasilkan teks padanan dalam bahasa sasaran yang mengkomunikasikan pesan serupa atau dengan kata lain penerjemahan adalah komunikasi pesan dari bahasa sumber ke bahasa sasaran dengan mennggunakan teks yang ekuivalenl. Definisi yang lain menurut Rochayal Machali (2009:26) menyebutkan bahwa penerjemahan adalah upaya "mengganti" teks bahasa sumber dengan teks yang sepadan dalam bahasa sasaran dan yang diterjemahkan adalah makna sebagaimana yang dimaksud oleh pengarang/penulis dengan menegaskan bahwa terjemahan lisan maupun tulisan memberi tekanan pada makna atau pesan yang disampaikan, sehingga hal penting dalam terjemahan adalah bahwa terjemahan memiliki maksud dan makna yang sama persis dengan pesan bahasa sumbernya. Jenis-jenis penerjemahan. 


\section{Penerjemahan kata demi kata (Word for word translation).}

Jenis terjemahan ini sangat terikat pada tatanan kata. Penerjemah hanya mencari padanan kata bahasa sumber dalam bahasa sasaran tanpa mengubah susuan kata dan hanya dilakukan apabila kedua bahasa mempunyai struktur yang sama.

Contoh:

1. Saya pergi ke kantor setiap pagi. I go to office every morning.

2. Dia mengajar kelas empat.

She teaches grade four.

\section{Penerjemahan Bebas (Free translation).}

Penerjemahan jenis ini selalu terikat oleh system. Penerjemah harus mampu menangkap pesan dalam bahasa sumber pada tatanan paragraf atau wacana secara utuh dan kemudian mengalihkan serta mengungkapkannya dalam bahasa sasaran. Hal ini sukar dilakukan terutama oleh penerjemah yang belum berpengalaman.

Contoh: 1 . Membolos.

$$
\text { To play truant. }
$$

2. Membahas.

To klick something around.

3. Sambil menyelam minum air.

To kill two birds with one stone.

\section{Penerjemahan Harafiah (Literal Translation).}

Tabel 1. Penerjemahan Harafiah

\begin{tabular}{llcc}
\hline Kalimat bahasa Inggri s & Terjemahan kata demi kata & $\begin{array}{c}\text { Terjemahan } \\
\text { harafiah }\end{array}$ & $\begin{array}{c}\text { Terjemahan } \\
\text { bebas }\end{array}$ \\
\hline $\begin{array}{l}\text { His heart is in the } \\
\text { right place }\end{array}$ & $\begin{array}{l}\text { Kepunyaannya hati adalah } \\
\text { dalam itu tempat }\end{array}$ & $\begin{array}{l}\text { Hatinya berada } \\
\text { di tempat yang } \\
\text { benar }\end{array}$ & Dia baik hati \\
\hline
\end{tabular}

Sumber: Peneliti, 2019

Penerjemahan harafiah terletak antara penerjemahan bebas (free translation) dan penerjemahan kata demi kata (word for word translation). Penerjemahan jenis ini dimulai dengan penerjemahan kata demi kata akan tetapi dibuat perubahan dan disesuaikan dengan kata dalam bahasa sasaran. Penerjemahan jenis ini biasanya diterapkan apabila struktur kalimat bahasa sumber berbeda dengan struktur kalimat bahasa sasaran.

\section{Penerjemahan Pragmatik (Pragmatic Translation).}

Penerjemahan pragmatik mengacuh pada penerjemahan suatu pesan yang menekankan pada ketepatan informasi yang disampaikan dalam bahasa sumber .Jika diperlukan, penerjemah harus menambah beberapa informasi untuk membuat terjemahannya lebih jelas bagi pembaca. Jenis penerjemahan ini tidak begitu menekankan aspek bentuk bahasa sumber seperti pada penerjemahan dokumen-dokumen teknik dan niaga yang lebih menitikberatkan informasi atau fakta.

Contoh:

White cross baby powder is soft and smoothing. It absorbs moisture and keeps baby cool and comfortable. It contains chlorhexidine, and antiseptic widely used in hospitals and clinics. 
White cross baby powder lembut dan halus, menyerap kelembaban, menjaga kesegaran dan kenyamanan bayi. Mengandung chlorhexidine dan antiseptic yang banyak digunakan di rumah sakit dan klinik.

\section{Penerjemahan Estetik-Puitik (Esthetic-Poetic Translation).}

Penerjemahan jenis ini tidak hanya menekankan penyampaian informasi, tapi juga pada kesan, emosi dan perasaan dengan mempertimbangkan bahasa sasaran. Demikian kompleksnya penerjemahan jenis ini sehingga Grace (1985:25) mengatakan: suatu sastra tidak mungkin diterjemahkan ke dalam bahasa lain namun ada juga terjemahan-terjemahan sastra yang baik.

\section{Penerjemahan Etnografik.}

Jenis terjemahan ini membutuhkan penjelasan konteks budaya bahasa sumber dan bahasa sasaran. Penerjemah harus peka terhadap cara bagaimana kata-kata itu digunakan dalam konteks budaya bahasa sumber dan bahasa sasaran. Apabila sebuah kata bahasa sumber belum ada atau tidak mempunyai padanan dalam bahasa sasaran yang disebabkan oleh berbedanya budaya pemakaian kedua bahasa tersebut, maka akan sulit dilakukan terjemahan etnografik. Kata Modin, misalnya tidak mempunyai padanan dalam bahasa Inggris dan untuk mengatasi masalah seperti ini, biasanya penerjemah membiarkan kata Modin itu tetap tertulis dalam bahasa Indonesia. Kemudian penerjemah memberi anotasi atau keterangan perihal arti kata tersebut.

\section{Penerjemahan Semantik (Semantic Translation)}

Fokus terjemahan semantik adalah pencarian padanan pada tatanan kata dengan terikat pada budaya bahasa sumber. Penerjemah berusaha mengalihkan makna kontekstual bahasa sumber yang sedekat mungkin dengan struktur sintaksis dan semantik bahasa sasaran. Hal ini dimaksudkan untuk mempertahankan bentuk kalimat dalam bahasa sasaran agar sama dengan bahasa sumber.

\section{Penerjemahan Dinamik (Dynamic Translation).}

Jenis penerjemahan ini disebut juga penerjemahan yang wajar. Pesan dalam bahasa sumber dialihkan dan diungkapkan dengan ungkapan-ungkapan yang lazim dalam bahasa sasaran. Contoh:

The author has organized this book since 1995.

Tidak wajar kalau diterjemahkan menjadi:

Penulis telah mengorganisasikan buku ini sejak 1995.

Lebih wajar:

Penulis telah menyusun buku ini sejak 1995.

\section{Penerjemahan Komunikatif dan Semantik.}

Newmark (1981) membahas tentang penerjemahan komunikatif dan semantik termasuk secara singkat tentang hakikat penerjemahan mulai dari periode pra-linguistik modern abad ke 19 sampai pada timbulnya saling pendapat tentang apakah penerjemah harus lebih memperhatikan bahasa sumber atau bahasa sasaran dan adanya pandangan pada waktu itu yang memberi penekanan pada pencarian padanan unsur-unsur formal, seperti kata atau struktur kata.

\section{Penerjemahan Linguistik (Linguistic Translation).}

Penerjemahan linguistik hanya berisi informasi linguistik yang implisit dalam bahasa sumber yang dijadikan eksplisit dan yang dalam perubahan bentuk digunakan transformasi balik dan analisis komponen makna. Dengan demikian kita hanya menemukan informasi linguistik seperti morfem, kata, frasa, klausa dan kalimat. Pada umumnya penerjemahan linguistik 
diterapkan jika terdapat ketaksamaan dalam bahasa sumber baik pada tatanan kata, frasa, klausa ataupun pada tatanan kalimat, terutama kalimat kompleks.

\section{Penerjemahan Komunikatif (Communicative Translation).}

Mengacuh pada hakikat komunikasi, mengemukakan pandangannya tentang fungsi terjemahan sebagai alat komunikasi melalui pernyataan sebagai berikut: penerjemahan komunikatif mempersyaratkan agar bahasa terjemahan mempunyai bentuk, makna dan fungsi. Hal ini perlu diingat karena bisa jadi suatu kalimat sudah benar dari segi bentuk tapi maknanya tidak logis atau bentuk dan maknanya sudah benar namun fungsinya kurang tepat.

Contoh:
1. Could you told me the way to the meeting room? (bentuknya salah tapi maknanya logis).
2. Could you tell the door the way to the meeting room? (bentuknya benar tapi maknyanya salah).
3. Could you tell me the way to the meeting room? (bentuk dan maknyanya benar).

\section{METODE PENELITIAN}

Metode penelitian adalah cara untuk mendapatkan data dengan tujuan dan kegunaan tertentu( Sugiyono, 2018) dan penelitian kwalitatif ( Arifin, 2011) adalah penelitian untuk menjawab permasalahan yang memerlukan pemahaman secara mendalam dalam konteks waktu dan situasi yang bersangkutan, dilakukan secara wajar dan a adanya manipulasi serta jenis data yang dikumpulkan terutama data kwalitatif. Menurut Emzir (2016) data dalam penelitian ini data berupa kata, kalimat, wacana dan gambar yang diperoleh secara langsung oleh peneliti di lapangan sedangkan menurut Moleng dalam Syafi'i (2014) penelitian jenis ini memanfaatkan latar alamiah dengan maksud menafsir fenomena yang terjadi dan dilakukan dengan melibatkan berbagai teknik seperti wawancara observasi dan dokumentasi.

\section{Lokasi dan objek penelitian.}

Lokasi penelitian adalah jurusan Pariwisata Politeknik Negeri Manado dan objek penelitian adalah seluruh mahasiswa semester IV tahun akademik 2018/ 2019.

\section{Populasi dan sampel.}

Populasi dalam penelitian ini adalah seluruh mahasiswa semester IV yang berjumlah 6 kelas sedangkan sampelnya akan dipilih secara acak 15 orang untuk experimental group dan 15 orang untuk control group.

\section{Sumber data.}

Menurut Sugiyono (2013: 2), kriteria dalam penelitian kwalitatif adalah data yang pasti yaitu data yang sebenarnya sebagaimana adanya, bukan data yang sekedar yang terlihat dan terucap, tapi data yang mengandung makna di balik apa yang terlihat dan terucap tersebut. Dalam penelitian ini data utama diperoleh dari hasil tes awal, tes kemajuan setelah perlakuan pertama, tes kemajuan setelah perlakuan kedua terhadap experimental class dan tes akhir bagi kedua kelas. Sedangkan data data lain diperoleh dari dokementasi yang dimiliki Jurusan Pariwisata politeknik Negeri Manado dan sumber sumberlain seperti perpustakaan dan internet.

\section{Instrumen penelitian.}

Dalam penelitian ini yang menjadi instrument penelitian utama adalah para peneliti sebagai perencana, pelaksana, pengumpul data, penafsir dan akhirnya menjadi pembahas dan pelapor hasil peneliti (Burhanuddin, 2013). 


\section{Tahapan penelitian.}

1. Penetapan rumusan masalah dan tujuan penelitian. Pada tahap ini, peneliti merumuskan masalah dan menentukan tujuan penelitian yang akan dicapai pada akhir penelitian ini.

2. Pengamatan awal dan sosialisasi maksud dan tujuan penelitian kepada mahasiswa semester IV jurusan pariwisata baik yang menjadi experimental group maupun yang control group.

3. Pretest bagi kedua kelompok.

4. Perlakuan (treatment) mulai dilakukan untuk mengembangkan keterampilan menulis bahasa Inggris akademik dengan menggunakan terjemahan bagi experimental group dan tanpa menggunakan metode terjemahan bagi control group.

5. Post test bagi kedua kelompok dengan menggunakan materi tes yang sama.

6. Analisa data.

7. Pengambilan kesimpulan.

8. Seminar hasil.

9. Penulisan laporan akhir.

10. Publikasi laporan akhir.

\section{HASIL DAN PEMBAHASAN}

Pengembangan pembelajaran adalah usaha meningkatkan kualitas proses pembelajaran baik secara materi maupun metode dan subtitusinya. Faktor proses belajar (learning process); adanya kegiatan belajar yang menyebabkan terjadinya perubahan dalam pengetahuan dan perilaku individu peserta pembelajaran pada pencapaian keterampilan. Untuk mencapai keterampilan dalam academic writing dibutuhkan ide, kosa kata dan tata bahasa. Sejalan dengan hal tersebut maka dalam penelitian ini peneliti telah menentukan satu kelas untuk dijadikan sebagai kelas percobaan (Experimental group) dan kelas lainnya sebagai pembanding (Control group). Pada Experimental group, peneliti menggunakan pengajaran academic writing melalui metode penerjemahan, sedangkan pada Control group digunakan metode pembelajaran biasa ( tanpa metode penerjemahan), namun sebelum diadakan pengukuran untuk kedua metode tersebut, kedua kelas itu diberi tes awal dengan materi yang sama.

Materi tes adalah essay singkat yang harus dikerjakan dengan ukuran waktu yang sama, setelah peneliti menjelaskan beberapa hal yang berhubungan dengan Essay tersebut. Adapun hasil tes kedua group tersebutdapat dilihat pada table berikut ini.

Tabel 2. Hasil Pretest Experimental Group dan Control Group

\begin{tabular}{ccc}
\hline No & Experimental Group & Control Group \\
\hline 1 & 60 & 60 \\
\hline 2 & 65 & 55 \\
\hline 3 & 55 & 60 \\
\hline 4 & 60 & 65 \\
\hline 5 & 50 & 60 \\
\hline 6 & 60 & 50 \\
\hline 7 & 55 & 70 \\
\hline 8 & 50 & 65 \\
\hline 9 & 70 & 70 \\
\hline 10 & 60 & 55 \\
\hline 11 & 70 & 60 \\
\hline 12 & 60 & 70 \\
\hline 13 & 55 & 50 \\
\hline 14 & 65 & 55 \\
\hline 15 & 70 & 55 \\
\hline Total & 905 & 900 \\
\hline
\end{tabular}

Sumber: Hasil pengolahan data, 2019 
Dari hasil pre test yang ditunjukkan dalam tabel 2, ternyata kemampuan mengerjakan essay singkat kedua grup tidaklah jauh berbeda, karena eksperimental grup mendapat nilai 905 dan control grup mendapatkan nilai 900 , jadi hanya berbesa 5 point, suatu perbedaan yang tidak signifikan karena bila dipersentasikan hanya sebesar $0,55 \%$. Selanjutnya kedua kelas diberi materi pembelajaran yang sama yaitu membuat essay ilmiah singkat, Pada tahap ini peneliti mulai menggunakan metode penerjemahan untuk grup ekperimen dengan cara menerjemahkan kalimat - kalimat dari bahasa Indonesia ke bahasa Inggris, selanjutnya diadakan pembahasan hasil terjemahan dalam tataran kalimat ( Sentence level translation) hal ini dilakukan dalam upaya meningkatkan grammar. Sementara untuk control group pembuatan essay ini langsung pada menulis sesuai instruksi yang ada, dengan kalimat - kalimat yang biasa ada dalam sebuah essay tanpa diterjemahkan. Diakhir topik pembelajaran ini, diadakan tes yang kedua yang dinamakan tes setelah perlakuan pertama. Hasil tes ini dapat dilihat pada table berikut.

Tabel. 3. Tes Setelah Perlakuan Pertama.

\begin{tabular}{ccc}
\hline No & Experimental Group & Control Group \\
\hline 1 & 70 & 65 \\
\hline 2 & 75 & 65 \\
\hline 3 & 60 & 60 \\
\hline 4 & 70 & 65 \\
\hline 5 & 60 & 60 \\
\hline 6 & 70 & 60 \\
\hline 7 & 65 & 75 \\
\hline 8 & 65 & 65 \\
\hline 9 & 80 & 75 \\
\hline 10 & 70 & 60 \\
\hline 11 & 80 & 55 \\
\hline 12 & 75 & 60 \\
\hline 13 & 65 & 75 \\
\hline 14 & 75 & 55 \\
\hline 15 & 75 & 60 \\
\hline Total & 1.055 & 965 \\
\hline
\end{tabular}

Sumber: Hasil pengolahan data, 2019

Dari hasil tes diatas dapat diketahui bahwa, nilai yang diperoleh kedua grup ini sudah mulai berbeda secara signifikan yaitu eksperimen grup mencapai nilai 1.055, sedangkan control grup hanya mencapai 965. Bila dibandingkan dengan hasil tes pertama maka terdapat kenaikan sebesar 150 poin untuk total nilai eksperimen grup, yang secara rata - rata kelas terdapat 15 point kenaikan keterampilan dan pengetahuan dari masing - masing mahasiswa yang ada di eksperimen grup ini. Sementara untuk control grup juga mengalami kenaikan sebesar 65 poin untuk total nilai control grup, yang secara rata - rata setiap mahasiswa mendapat kenaikan sebesar 4,3 point. Bila dihitung selisih kenaikannya antara tes awal dan tes perlakuan satu, terdapat 90 poin berarti secara rata - rata kelas, setiap mahasiswa di eksperimen grup meningkat 6 poin lebih tinggi dari mahasiswa yang ada di control grup $(90 / 15=6)$. Setelah tes perlakuan pertama, peneliti melanjutkan materi pembelajaran dengan cara yang sama, yaitu eksperimen grup diajar dengan metode penerjemahan paragraph dari bahasa Indonesia ke bahasa Inggris (Paragraph Level Translation) hal ini dilakukan untuk meningkatkan pemahaman unity dan coherence dalam sebuah paragraph atau pemahaman yang lebih mendalam tentang struktur paragraf. Sementara untuk control grup diberi penjelasan tentang 
unity dan coherence tanpa menggunakan metode penerjemahan, setelah selesai penjelasan berbagai hal yang berhubungan dengan paragraf, kedua grup kemudian di tes untuk mengetahui kemajuan yang diperoleh. Hasil tes kedua grup ini dinamakan tes perlakuan kedua yang dapat dilihat pada tabel dibawah ini:

Tabel 4: Tes Setelah Perlakuan Kedua

\begin{tabular}{ccc}
\hline No & Experimental Group & Control Group \\
\hline 1 & 80 & 65 \\
\hline 2 & 85 & 65 \\
\hline 3 & 75 & 65 \\
\hline 4 & 80 & 70 \\
\hline 5 & 65 & 65 \\
\hline 6 & 80 & 65 \\
\hline 7 & 75 & 75 \\
\hline 8 & 75 & 70 \\
\hline 9 & 85 & 75 \\
\hline 10 & 75 & 60 \\
\hline 11 & 85 & 60 \\
\hline 12 & 85 & 65 \\
\hline 13 & 80 & 75 \\
\hline 14 & 80 & 60 \\
\hline 15 & 80 & 60 \\
\hline Total & 1.185 & 995 \\
\hline Su & & \\
\hline
\end{tabular}

Sumber: Hasil pengolahan data, 2019

Dari tabel 4 diatas diketahui bahwa, eksperimen grup mencapai 1185 poin sementara control grup hanya mencapai 995 point, jadi selisih antara kedua grup ini ada sebesar 190 poin. Hal ini berarti secara rata - rata setiap mahasiswa yang ada di eksperimen grup nilainya meningkat sebesar 13 poin bila dibandingkan dengan mahasiswa yang ada di control grup. Nilai rata - rata untuk eksperimen grup berada di 79 poin sementara di control grup baru mencapai 66 point, jadi ada perbedaan sebesar 13 point. Selanjutnya dilanjutkan pemberian materi sesuai rencana pembelajaran semester, dalam aktivitas ini kedua grup tidak lagi diberi perlakuan yang berbeda. Hal ini dilakukan untuk mengetahui apakah metode penerjemahan efektif untuk mengembangkan kemampuan mahasiswa dalam menulis essay. Setelah menyelesaikan pembelajaran ini mahasiswa di tes lagi, dan hasilnya seperti yang ada di tabel berikut ini: 
Tabel 5. Hasil Tes Akhir Experimental Group dan Control Group

\begin{tabular}{ccc}
\hline No & Experimental Group & Control Group \\
\hline 1 & 90 & 75 \\
\hline 2 & 90 & 70 \\
\hline 3 & 80 & 70 \\
\hline 4 & 85 & 75 \\
\hline 5 & 70 & 65 \\
\hline 6 & 90 & 65 \\
\hline 7 & 85 & 80 \\
\hline 8 & 85 & 80 \\
\hline 9 & 90 & 80 \\
\hline 10 & 80 & 65 \\
\hline 11 & 90 & 65 \\
\hline 12 & 85 & 75 \\
\hline 13 & 85 & 80 \\
\hline 14 & 90 & 70 \\
\hline 15 & 90 & 65 \\
\hline Total & 1285 & 1080 \\
\hline
\end{tabular}

Sumber: Hasil pengolahan data, 2019.

Dari tabel diatas diketahui bahwa, nilai untuk eksperimen grup telah mencapai 1285 , sementara untuk control grup mencapai 1.080 point, disini semakin jelas perbedaan dua grup tersebut, dimana perbedaannya mencapai 205 point. Bila dihitung rata - rata kelas ternyata di eksperimen grup setiap mahasiswa dapat mencapai 87 poin, sedangkan di control grup setiap mahasiswanya hanya mencapai 72 point, jadi ada perbedaan nilai sebesar 15 poin secara ratarata kelas.

Tabel 6. Perbandingan Nilai Tes Awal dan Nilai Tes Akhir Experimental Group dan Control Group

\begin{tabular}{ccccc}
\hline \multirow{2}{*}{$\begin{array}{c}\text { Nomor } \\
\text { Peserta }\end{array}$} & \multicolumn{2}{c}{ Experimental Group } & \multicolumn{2}{c}{ Control Group } \\
\cline { 2 - 5 } & PreTest & PostTest & Pre Test & Post Test \\
\hline 1 & 60 & 90 & 60 & 75 \\
\hline 2 & 65 & 90 & 55 & 70 \\
\hline 3 & 55 & 80 & 60 & 70 \\
\hline 4 & 60 & 85 & 65 & 75 \\
\hline 5 & 50 & 70 & 60 & 65 \\
\hline 6 & 60 & 90 & 50 & 65 \\
\hline 7 & 55 & 85 & 70 & 80 \\
\hline 8 & 50 & 85 & 65 & 80 \\
\hline 9 & 70 & 90 & 70 & 80 \\
\hline 10 & 60 & 80 & 55 & 65 \\
\hline 11 & 70 & 90 & 60 & 65 \\
\hline 12 & 60 & 85 & 70 & 75 \\
\hline 13 & 55 & 85 & 50 & 80 \\
\hline 14 & 65 & 90 & 55 & 70 \\
\hline 15 & 70 & 90 & 55 & 65 \\
\hline Total & 905 & 1285 & 900 & 1080 \\
\hline
\end{tabular}

Sumber: Hasil pengolahan data, 2019. 
Bila dihitung kenaikan yang dicapai oleh eksperimen grup dari awal sampai akhir pembelajaran ini terdapat selisih nilai sebesar 380 point, sedangkan control grup hanya mencapai 175 point dari nilai semula, hal ini membuktikan bahwa dengan adanya penerapan metode penerjemahan maka kemampuan mahasiswa dalam academic writing menjadi meningkat sebesar $42 \%$ dari nilai semula, sedangkan bila tidak menggunakan metode ini hanya meningkat sebesar $19 \%$, Jadi ada selisih yang cukup besar yaitu $23 \%$.

\section{SIMPULAN}

Berdasarkan analisa data di atas, dapatlah disimpulkan bahwa: ( 1) Ketrampilan Academic English sangatlah penting bagi mahasiswa semester atas Jurusan Pariwisata Politeknik Negeri Manado mengingat kemampuan bahasa Inggris Akademik menjadi prasyarat bagi keikut sertaan dalam magang di luar negeri dan juga bahkan di dalam negeri, dalam mengikuti studi lanjut baik di luar negeri maupun dalam negeri dan dalam melamar pekerjaan baik CPNS maupun Swasta ,(2) Ketrampilan Academic Writing ditunjang oleh kemampuan Tata Bahasa, Kosa kata dan pemahaman penyusunan gagasan dalam paragraph sehingga latihan penerjemahan mulai dari tingkat kata , kalimat, paragraph dan wacana sangatlah membantu pengembanagan ketrampilan Academic Writing mahasiswa sebagai perailahan ke penulisan Academic Writing dalam Bahasa Inggris dan (3) Penerapan Metode Penerjemahan sangat efektif dalam pengembangan ketrampilan Academic Writing mahasiswa. Terdapat perbedaan yang signifikan antara nilai rata rata pada tes akhir antara Experimental group dan Control Group yaitu sebesar $23 \%$.

\section{DAFTAR RUJUKAN}

Academic writing in English (AWE) (Sana.aatto.fi $>$ awe

Cambridge English Dictionary (https://dictionary Cambridge.org>development)

Denzim dan Lincoln.(2011). The SAGE hand book of qualitative research, fifth edition.LOS Ageles:Sage.

ESQ Course, (esqcourse.com>belajar.bahasa.inggris.akademik)

Keterampilan/ faktor-faktor yang menentukan keterampilan (https://Afrizal.wordpress.com)

Kridalaksana, Harimurti. (2013). Kamus Linguistik, Edisi Keempat, Gramedia Digital Magazine, Book and Newspaper Reader Apps Foundry.

Labare RV. (2009) Academic Writing Style-organizing your social research paper-research guides at university of southern California, 15 January 2009 (libguides.usc.edu>writing guide $>$ academic

Lincoln dan Guba.1985. Penelitian Kwalitatif (https://www/slideshare.net>buku>kualitatif)

Machali, Rochayah. (2009). Pedoman Bagi Penerjemah-Panduan Lengkap Bagi Anda Yang Ingin Jadi Penerjemah Professional. Bandung: Kaifa PT. Mizan Pustaka.

Mulyati, Yeti, (respiratory.ut.ac.id>PSGK 410-MI)

Putman, William H. (2009). Legal Research, Analysis and writing https://www.amazing.com>Legal_Research

Smaradipha, Galih. (2005). Bertutur dengan tulisan dalam (hhtp://www.rayakultura.com) diakses 1 oktober 2011.

Stiawan, Yasin. (2006). Perkembangan Bahasa. 16 Januari 2006 dalam (http://www.siaksaft.com) diakses pada tanggal 1 oktober 2011.

Sumarno, Alim. (2012). Penelitian Kausalitas Kompratif. Surabaya: e-learning UNESSA.

Undang-undang Republik Indonesia No.18 tahun 2012.Sistem Nasional Penelitian, pengembangan dan penerapan Ilmu Pengetahuan.Jakarta.

Wibowo Wahyu. (2001). Manajemen Bahasa.Jakarta: Gramedia Pustaka Utama. 